JEKPEND Jurnal Ekonomi dan Pendidikan

Volume 2 Nomor 1 Januari 2019. Hal. 28-36

p-ISSN: 2614-2139; e-ISSN: 2614-1973,

Homepage:http://ojs.unm.ac.id/JEKPEND

\title{
PERANGKAT PEMBELAJARAN EKONOMI BERBASIS LITERASI INFORMASI UNTUK KELAS X SMA NEGERI 8 BONE
}

\author{
${ }^{1}$ Wahidayanti, ${ }^{2}$ Herman, ${ }^{3}$ Inanna \\ ${ }^{1}$ Pendidikan Ilmu Sosial, Pascasarjana Universitas Negeri Makassar \\ Email: Wahidayantisalta@yahoo.com \\ ${ }^{2}$ Pendidikan Ilmu Sosial, Universitas Negeri Makassar \\ Email: hermanspdmsi1975@yahoo.co.id \\ ${ }^{3}$ Pendidkan Ekonomi, Universitas Negeri Makassar \\ Email: inanna@unm.ac.id
}

\begin{abstract}
The study aims at examining (i) the quality (valid,practical, and effective) of econmic learning tools based on literacy which had been developed, (ii) the students' response after being taugh by using economic learning tools based on literacy. The study was development research (Research and Development) which employed Thiagarajan and Sammen (Four-D) model which consisted of four stages, namely (1) define, (2) design, (3) development, and (4) dissimination. The test of learning tools was conducted to grade $\mathrm{X}$ student at SMAN 8 Bone of academic year 2018/2019. Data were collected using observation sheet, learning test, and questionnaire. Data were then analysed using descriptive analysis technique. The results of the development of economic learning tools based on literacy which cover the lesson plan, the students' worksheet, learning test indicated that (1) the economic learning tools based on literacy which had been developed produce a valid, practical, and effective learning tools, (2) the students' response after being based taught using economic learning tools based on literacy is positive. The conclusion which had been developed can improve learning outcomes on the lesson material of problems of economic and economic system.
\end{abstract}

Keywords: Learning Tools; Information Literacy; Learning Outcomes

\begin{abstract}
Abstrak. Tujuan penelitian ini adalah (i) Untuk Mengetahui kualitas (valid, praktis, dan efektif) perangkat pembelajaran ekonomi berbasis literasi informasi yang telah dikembangkan, (ii) Untuk mengetahui tanggapan peserta didik setelah di ajar menggunakan perangkat pembelajaran ekonomi berbasis literasi informasi. Penelitian ini merupakan penelitian pengembangan (Development and Research) menggunakan model dari Thiagarajan and Sammen ( Four-D) yang terdiri dari empat tahap yaitu: (1) Pendefinisian (Define), (2) Perancangan (Desain),(3) Pengembangan (Develop), dan (4) Penyebaran ( Dessiminate). Uji coba perangkat penbelajaran dilaksanakan pada peserta didik kelas X SMA Negeri 8 Bone tahun pelajaran 2018/2019. Pengumpulan data menggunakan lembar observasi, tes hasil belajar, dan angket. Selanjutnya data dianalisis dengan menggunakan teknik analisis deskriptif. Hasil penelitian pada pengembangan perangkat pembelajaran ekonomi berbasis literasi informasi yang meliputi: Rencana Pelaksanaan Pmebelajaran, Lembar Kerja Peserta Didik (LKPD) dan Tes Hasil Belajar menunjukkan bahwa (1) Perangkat pembelajaran ekonomi berbasis literasi informasi yang telah dikembangkan menghasilkan perangkat pembelajaran yang valid, praktis, dan efektif. (2) Tanggapan peserta didik setelah di ajar menggunakan perangkat pembelajaran ekonomi berbasis literasi adalah positif. Berdasarkan kesimpulan tersebut dapat dikemukakan bahwa perangkat pembelajaran ekonomi berbasis literasi yang telah dikembangkan dapat memperbaiki hasil belajar peserta didik pada materi masalah ekonomi dan sistem ekonomi.
\end{abstract}

Kata Kunci: Perangkat Pembelajaran; Literasi Informasi; Hasil Belajar 


\section{PENDAHULUAN}

Menurut Peraturan Menteri Pendidikan Nasioanal Republik Indonesia No.16 Tahun 2007 Tentang Standar Kualitas Akademik Dan Kompetensi Guru, adapun macam-macam kompetensi yang harus dimiliki oleh guru antara lain: kompetensi pedagogik, kompetensi kepribadian, kompetensi profesional dan komptensi sosial. Keempat kompetensi tersebut harus terintegrasi dalam kinerja guru. Setiap pendidik dalam satuan pendidikan berkewajiban menyusun rencana pelaksanaan pembelajaran (RPP) secara lengkap dan sistematis agar pembelajaran berlangsung secara interaktif, inspiratif, menyenagkan, dan dapat memotivasi peserta didik untuk berpartipasi aktif, sehingga peserta didik memperoleh ruang yang cukup untuk prakarsa kreatifitas dan kemandirian sesuai dengan bakat, minat dan perkembangan fisik serta psikologis peserta didik. Menurut Trianto (2013:81) untuk melaksanakan pengembangan perangkat pembelajaran diperlukan model-model pengembangan yang sesuai dengan sistem pendidikan.

Secara umum, rendahnya rata-rata perolehan nilai untuk kelompok mata pelajran ekonomi mengidentifikasikan bahwa proses pembelajaran belum dapat berlangsung sebagai mana mestinya. Hal tersebut banyak disebabkan konsep-konsep ekonomi sering disampaikan oleh guru kepada siswa sebagai fakta bukan sebagai peristiwa atau geajal dalam kehidupan sosial yang harus diamati dan di diskusikan, oleh karena itu pembeajaran ekonomi sebaiknya di pelajari dengan cara sedemikian rupa sehingga memungkinkan untuk dapat di gunakan dalam pemecahan masalah-masalah nyata yang dijumpai peserta didik.

Berdasarkan hasil observasi awal yang dilakukan terhadap kegiatan belajar mengajar yang berlangsung di SMA Negeri 8 Bone pada mata pelajaran ekonomi, diperoleh gambaran bahwa hasil belajar ekonomi kelas $\mathrm{X}$ jurusan IIS masih tergolong rendah. Hal ini dapat kita lihat dari hasil ekonomi pada tabel 1 di bawah ini.

Tabel 1. Rata-Rata Nilai Ekonomi Kelas X Tahun Pelajaran 2017/2018

\begin{tabular}{ccc}
\hline No & Kelas & Rata-rata nilai \\
\hline 1. & $\mathrm{X}$ iis 1 & 77 \\
2. & $\mathrm{X}$ iis 2 & 75 \\
3. & $\mathrm{X}$ iis 3 & 78 \\
\hline
\end{tabular}

Sumber: Guru ekonomi kelas X SMAN 8 Bone,2018

Hal ini menandakan bahwa siswa pada umumnya tidak banyak menggunakan cara-cara bertanya dalam usaha memperoleh pengetahuannya. Di sekolah tradisional cara-cara bertanya tidak banyak diajarkan kepada siswa melainkan hanya di suruh mendengarkan dan mengulang-ulang jawaban sebuah proses yang cukup kompleks akan telibat ketika seseorang berusaha mengubah informasi dan datamenjadi pengetahuan yang bermanfaat. Pembelajaran yang dirancang dengan baik menghasilkan pengetahuan yang dapat diterapkan secara luas. Menghafal fakta dan informasi bukan lagi merupakan keterampilan paling penting saat ini. Perubahan fakta dan informasi telah banyak terjadi sehingga yang diperlukan adalah pemahaman tentang bagimana memperoleh data dan informasi.

Menurut Trilling(2009) Pembelajaran abad 21 membelajarkan siswa agar menguasai (1) pelajaran ekonomi sebagai salah satu core subjek yang diperlukan pada abad ke-21, (2) keterampilan belajar dan inovasi, (3) keterampilan informasi media dan teknologi, serta (4) keterampilan hidup dan berkarir. Literasi informasi diperlukan bagi generasi abad ini untuk mengolah informasi. Sumber daya informasi menjadi faktor penting dalam dunia pendidikan, terutama diera sekarang ini. Dimana kemajuan disegala bidang, terciptanya peradaban modern, mampu bersaing dalam pasar dunia, dan sebagainya, adalah buah karya manusia yang berpengalaman. Manusia sebagai aktornya memiliki kecakapan untuk berbuat atau melakukan sesuatu sesuai dengan kebutuhan dan kemanfaatannya (Joner: 2008). Namun, membludaknya informasi pengetahuan ternyata belum memberikan jaminan kepada setiap orang untuk cepat beradaptasi dengannya. Hal ini terkait 
dengan bagaimana informasi itu dapat diakses atau tidak. Oleh karena itu, literasi informasi menjadi sangat penting dan menjadi kebutuhan, kaitannya dengann kebutuhan mengenali kebutuhan informasi, mencari sumber-sumber informasi, menelaah, menyaring, sampai dengan mengevaluasi konten informasi.

Untuk mengembangkan kemampuan dalam mengomunikasikan informasi, guru dapat membelajarkan siswa untuk mencari informasi. Guru membimbing siswa dalam memahami informasi itu biasa berasal dari berbagai sumber. Guru dapat mengarahkan siswa untuk memilah berbagai sumber tersebut sesuai kebutuhan secara kritis. Selain hal tersebut, guru juga dituntut untuk membimbing siswa dalam mengomunikasikan informasi yang diolah tersebut secara lisan atau tulisan.

Literasi informasi secara umum sebagai kemelekan atau keabsahan informasi literasi. Literasi informasi yaitu kemampuan memanfaatkan berbagai alat-alat informasi serta sumber-sumber informasi primer untuk memecahkan masalah mereka. Menurut Emi (2015) literasi informasi merupakan sebuah pemhaman dari seperangkat atau serangkaian kemampuan/keterampilan yang dimiliki dan memungkinkan untuk mendapatkan jalan keluar/solusi untuk memecahkan masalah.

Menurut Mishra (2010) bahwa literasi informasi dapat diartikan sebagai sebuah keahlian dalam mengakses dan mengevaluasi informasi secara efektif untuk memecahkan masalah dan membuat keputusan. Seseorang yang memiliki keahlian ini tahu bagaimana belajar untuk belajar karena mereka tahu bagaimana mengelolah informasi, mengevaluasi, memilah-milah dan menggunakannya sesuai dengan etika.

Menurut Joner (2008) literasi informasi bermanfaat dalam persaingan di era globalisasi informasi sehingga pintar saja tidak cukup tetapi yang utama adalah kemampuan dalam belajar terus menerus. Dalam proses pembelajaran literasi informasi guru mendorong para peserta didik untuk melakukan kerja sama seperti diskusi. Dalam proses belajar, guru tidak mendominasi seperti lazimnya pada saat ini, sehingga peserta didik dituntut berbagai informasi informasi dengan peserta didik lainnya dan saling belajar mengajar sesama mereka.
Literasi merupakan inti pembelajaran seumur hidup dan merupakan dasar bagi manusia di era digital ini. Literasi informasi adalah : (1) sebagai kunci dan pedoman seseorang dalam mengakses informasi secara efektif serta penggunaan dan pembuatan konten dalam mendukung pembangunan ekonomi, pendidikan, kesehatan, pelayanan manusia dan aspek lainnya; (2)kemampuan dasar dalam mempelajari teknologi informasi; (3) kemampuan yang dimiliki seseorang dalam mencari, menemukan, menganalisis, mengevaluasi, mengkomunikasikan informasi yang berfungsi dalam pemenuhan kebutuhan informasi yang akan memecahkan berbagai masalah. Penguasaan teknologi informasi juga akan memudahkan seseorang memiliki literasi informasi. Oleh karena itu literasi informasi merupakan proses pembelajaran seumur hidup yang akan menjadi bekal seseorang dalam mencari informasi bukan hanya dalam pendidikan.

Konsep definisi literasi informasi mengarah kepada satu kesimpulan bahwa literasi informasi yakni terjadi dari serangkaian kemampuan yang dibutuhkan seseorang untuk : (1) menyadari kapan informasi dibutuhkan, (2) mencari informasi dari berbagai sumber, (3) mengevaluasi informasi yang telah diperoleh, (4) menggunakan informasi untuk berbagai keperluan, (5) mengkomunikasikan informasi tersebut secara selektif dan etis (Joner: 2008).

Menurut Emi (2015) model literasi informasi terbagi kedalam enam bagian :

1) Mengidentifikasi kebutuhan informasi.

2) Menelusuri informasi

3) Mengetahui informasi lokal

4) Mengorganisikan informasi

5) Mempersentasikan informasi

6) Mengevaluasi informasi

Adapun menurut Doyle dalam Apriyanti (2010) mengungkapkan bahwa seseorang disebut memiliki keahlian literasi informasi jika seseorang tersebut memiliki: (a) mampu menyadari kebutuhan informasinya, (b) mampu mengidentifikasi sumber-sumber potensial dari suatu informas, (c) mampu mengakses berbagai sumber informasi termasuk teknologi dasar lainnya, (d) mampu mengevaluasi informasi, (e) mampu mengelola informasi untuk mengaplikasikan/ mempraktikannya. 


\section{METODE}

Jenis penelitian ini merupakan penelitian pengembangan (Research and Development), yang bertujuan untuk menghasilkan sebuah produk berupa perangkat pembelajaran (RPP), Lembar Kerja Peserta Didik (LKPD), dan Tes Hasil Belajar (THB), dengan menggunakan model Four-D yaitu Define, Desain, Develop, dan Dessiminate.

Intrument dalam penelitian ini menggunakan lembar validasi perangkat pembelajaran, lembar pengamatan, lembar angket respon peserta didik dan tes hasil belajar. Dengan teknik pengumpulan data dalam penelitian ini dikumpulkan melalui tiga teknik yaitu : data uji kevalidan, data uji kepraktisan, dan data uji keefektifan.

Analisis data dilakukan dalam pengembangan perangkat pembelajaran ini adalah teknik analisis statistik deskriptif, data yang dianalisis yaitu : analisis data kevalidasi perangkat pembelajaran, analisis data kepraktisan, dan analisis data keefektifan.

\section{HASIL DAN PEMBAHASAN} Analisis Data Kevalidan

Tabel 2. Data rangkuman Hasil Validasi RPP

\begin{tabular}{llll}
\hline No. & \multicolumn{1}{c}{ Aspek penilaian } & $\mathrm{X}$ & Ket \\
\hline 1 & Kesesuain tujuan & 3,20 & Valid \\
2 & Materi yang disajikan & 3,75 & Valid \\
3 & Bahasa & 4,00 & Valid \\
4 & Sarana dan prasarana pembelajaran & 4,00 & Valid \\
5 & Metode dan kegiatan pembelajaran & 3,75 & Valid \\
6 & Alokasi waktu & 3,50 & Valid \\
\hline Rata-rata penilaian total & 3,75 & Valid \\
\hline Rata-rata penilaian total & 3,75 & Valid \\
\hline
\end{tabular}

Berdasarkan tabel 2 menunjukkan bahwa nilai rata-rata kevalidan berada pada kategori Valid, yaitu berada pada $(3,5 \leq \bar{x}<4,0)$. Penilaian secara umum oleh para ahli RPP adalah baik dan dapat digunakan dengan sedikit revisi.Rata-rata penilaian validator terhadap RPP dari aspek kesesuaian tujuan, materi,bahasa, sarana dan alat bantu pembelajaran, metode dan alokasi waktu adalah 3,75 dengan kategori sangat valid. Hal ini berarti RPP disusun dengan prinsip-prinsip pengembangan RPP, dan seluruh komponen dalam penyusunan RPP telah tercantum, sehingga RPP ini dapat diterapkan langsung dalam kegiatan pembelajaran

Secara umum nilai rata-rata total validan rencana pelaksanaan pembelajaran yang diperoleh termasuk dalam kategori valid. Sehingga ditinjau dari keseluruhan aspek, rencana pelaksanaan pembelajaran dinyatakan memenuhi kriteria kevalidan. Hasil akhir revisi perangkat tersebut merupakan yang dipakai pada uji coba perangkat.

Tabel 3. Validasi Lembar Kerja Peserta Didik (LKPD)

\begin{tabular}{clcc}
\hline No. & Aspek yang dinilai & $\bar{x}$ & Ket. \\
\hline 1 & Aktivitas & 3,5 & Valid \\
2 & Materi yang disajikan & 3,71 & Valid \\
3 & Bahasa & 3,36 & Valid \\
4 & Waktu & 3,50 & Valid \\
\hline 5 & Rata-rata total & 3,52 & Valid \\
\hline
\end{tabular}

Berdasarkan tabel 3 menunjukkan bahwa nilai rata-rata kevalidan berada pada kategori 
valid yaitu berada pada $(3,5 \leq \bar{x}<4,0)$. Penilaian

baik dan dapat digunakan dengan sedikit revisi. secara umum oleh para ahli untuk LKPD adalah

Tabel 4. Hasil Validasi Tes Hasil Belajar

\begin{tabular}{llcl}
\hline No & Aspek yang dinilai & $\bar{x}$ & Ket. \\
\hline 1 & Karakteristik soal & 3,80 & Valid \\
2 & Konstruksi & 3,50 & Valid \\
3 & Bahasa & 4,00 & Valid \\
\hline 4 & Rata-rata total & 3,77 & Valid \\
\hline
\end{tabular}

Berdasarkan tabel .4 menunjukkan bahwa nilai rata-rata kevalidan berada pada kategori valid yaitu berada pada $(3,5 \leq \bar{x}<4,0)$. Penilaian secara umum oleh para ahli untuk THB adalah baik dan dapat digunakan dengan sedikit revisi.

Tabel 5. Hasil Validasi Instrumen Penelitian

\begin{tabular}{|c|c|c|c|c|}
\hline No & Instrument penelitian & $\bar{x}$ & Keterangan & $\mathrm{R}$ \\
\hline 1 & Lembar pengamatan keterlaksanaan perangkat pembelajaran & 4,00 & Valid & 1 \\
\hline 2 & Lembar pengamatan aktivitas peserta didik & 3,92 & Valid & 1 \\
\hline 3 & Lembar respon peserta didik terhadap perangkat pembelajaran. & 4,00 & Valid & 1 \\
\hline 4 & Lembar repon guru terhadap perangkat pembelajaran & 4,00 & Valid & 1 \\
\hline
\end{tabular}

Dari tabel.5 menunjukkan bahwa nilai rata-rata kevalidan berada pada kategori valid yaitu berada pada $(3,5 \leq \bar{x}<4,0)$. Yang artinya bahwa instrumen penelitian dapat digunakan dalam penelitian.

\section{Analisis Kepraktisan}

Tabel 6. Hasil pengamatan keterlaksanaan perangkat pembelajaran'

\begin{tabular}{clcl}
\hline No & \multicolumn{1}{c}{ Aspek } & Rata-rata & Keterangan \\
\hline 1 & Sintaks & 3,56 & Terlaksan seluruhnya \\
2 & Interaksi sosial & 3,62 & Terlaksan seluruhnya \\
3 & Prinsip reaksi & 3,64 & Terlaksan seluruhnya \\
4 & Sistem pendukung & 3,60 & Terlaksan seluruhnya \\
5 & Dampak pengiring & 3,60 & Terlaksan seluruhnya \\
6 & Perangkat pembelajaran & 3,86 & Terlaksan seluruhnya \\
\hline & Rata-rata total (x) & 3,64 & Terlaksan seluruhnya \\
\hline
\end{tabular}

Hasil analisis data observasi pengamat tentang keterlaksanaan perangkat pembelajaran dari hasil uji coba termasuk kategori terlaksana seluruhnya sehingga perangkat ini berada dalam kategori praktis.

Tabel 7 Hasil Respon Guru Terhadap Pembelajaran Berbasis Literasi informasi

\begin{tabular}{llcl}
\hline No & Aspek & $\bar{x}$ & Keterangan \\
\hline 1 & $\begin{array}{l}\text { Penilaian terhadap perangkat pembelajaran } \\
\text { dan instrumen penilaian hasil belajar }\end{array}$ & 85,55 & Sangat positif \\
2 & $\begin{array}{l}\text { Dukungan perangkat pembelajaran pada } \\
\text { pelaksanaan tugas mengajar di kelas }\end{array}$ & 92,97 & Sangat positif \\
3 & $\begin{array}{l}\text { Pertanyaan/ pernyataan proses } \\
\text { pembelajaran }\end{array}$ & 93,75 & Sangat positif \\
\hline & Rerataan & 90,76 & Sangat positif \\
\hline
\end{tabular}

Pada tabel 7 terlihat bahwa persentase respon guru terhadap pembelajaran yang menggunakan perangkat pembelajaran berbasis literasi secara keseluruhan berada dalam 
kategori sangat baik atau sangat positif berarti berada dalam kategori praktis.

Tabel 8 Hasil Respon Peserta Didik Terhadap Pembelajaran Berbasis Literasi

\begin{tabular}{|c|c|c|c|}
\hline No & Aspek & $\bar{x}$ & Keterangan \\
\hline 1 & $\begin{array}{l}\text { Perangkat pembelajaran } \\
\text { pembelajaran }\end{array}$ & 92,55 & SP \\
\hline 2 & LKPD & 94,86 & SP \\
\hline & Rata-rata total \% & 93,36 & $\mathrm{SP}$ \\
\hline
\end{tabular}

Pada tabel 8 terlihat bahwa persentase

pembelajaran berbasis literasi secara keseluruhan rata-rata respon peserta didik terhadap pembelajaran yang menggunakan perangkat berada dalam kategori sangat baik aau sangat positif.

\section{Analisis keefektifan}

Tabel 9 Hasil pengamatan kemampuan guru mengelolah pembelajaran

\begin{tabular}{llll}
\hline No & Aspek yang diamati & Rata-rata & Keterangan \\
\hline 1 & Kegiatan awal & 3,88 & Sangat baiki \\
2 & Kegiatan inti & 3,81 & Sangat baiki \\
3 & Kegiatan akhir & 3,96 & Sangat baiki \\
4 & Pengamatan suasana kelas & 4,00 & Sangat baiki \\
\hline & Rata-rata total (x) & 3.92 & Sangat baiki \\
\hline
\end{tabular}

Hasil analisis data observasi kemampuan guru mengelola pembelajaran berada pada

kategori sangat baik, artinya berada pada kategori efektif.

Tabel .10 Hasil Pengamatan Aktivitas Peserta Didik

\begin{tabular}{llcl}
\hline No & Aktivitas peserta didik & $\bar{x}$ & Ketegori \\
\hline 1 & Literasi awal & 89,86 & SB \\
2 & Merumuskan masalah & 90,77 & SB \\
3 & Literasi lanjutan & 88,27 & SB \\
4 & Mengumpulkan data serta analisis data & 92,82 & SB \\
5 & Literasi penguatan & 88,69 & SB \\
6 & Mengkomunikasikan dan merumskan & 91,99 & SB \\
& kesimpulan & & \\
\hline & Persentase aktivitas peserta didik & 90,4 & SB \\
\hline
\end{tabular}

Pada tabel 10 menunjukkan bahwa ratarata persentase yang didapatkan dari setiap aspek peserta didik berada pada kategori sangat baik. Secara umum dapat dikemukakann bahwa aspek aktivitas yang diamati memiliki frekuensi dan persentase yang tinggi, ini berarti aktivitas peserta didik sesuai yang diharapkan karena berada pada kategori sangat baik, karena persentase yang di dapatkan dari pertemuan pertama sampai pertemuan keempat rata-rata persentasenya mencapai $90 \%$.

Tabel 11 Hasil Respon Peserta Didik Terhadap Pembelajaran Berbasis Literasi informasi

\begin{tabular}{llccl}
\hline No & Aspek & & $\bar{x}$ & Keterangan \\
\hline 1 & $\begin{array}{l}\text { Perangkat pembelajaran dan } \\
\text { pembelajaran }\end{array}$ & proses & 92,55 & SP \\
2 & LKPD & & 94,86 & SP \\
\hline & Rata-rata total \% & 93,36 & SP \\
\hline
\end{tabular}

Pada tabel 11 terlihat bahwa persentase rata-rata respon peserta didik terhadap pembelajaran yang menggunakan perangkat pembelajaran berbasis literasi informasi secara 
keseluruhan berada dalam kategori sangat baik atau sangat positif.

Tabel 12. Rekapitulasi Skor Tes Hasil Belajar Peserta Didik

\begin{tabular}{llll}
\hline Rentang skor & Jumlah peserta didik & Nilai huruf & Interpretasi \\
\hline $0-20$ & - & - & Tidak baik \\
$21-40$ & - & - & Kurang baik \\
$41-60$ & - & - & Cukup \\
$61-80$ & 18 & B & Baik \\
$81-100$ & 9 & A & Sangat baik \\
\hline
\end{tabular}

Dari tabel 12. menunjukkan bahwa persentase rata-rata pencapaian hasil belajar peserta didik berada pada kategori sangat baik.

\section{Kualitas perangkat pembelajaran ekonomi berbasis literasi informasi.}

Secara umum, hasil penilaian para ahli terhadap perangkat pembelajaran yang meliputi Rencana Pelaksanaan pembelajaran (RPP), Lembar Kerja Peserta (LKPD), dan tes Hasil Belajar (THB). Di uraiakan sebagai berikut:

\section{a. Kevalidan}

1) Rencana pelaksanaan pembelajaran (RPP)

Rata-rata penilaian validator terhadap RPP dari aspek kesesuian tujuan, materi, bahasa, sarana, dan alat bantu pembelajaran, metode dan alokasi waktu adalah 3,75 dengan kategori sangat valid. Hal ini berarti RPP disusun sesuai dengan prinsip-prinsip pengembangan RPP, dan seluruh Komponen dalam penyusunan RPP telah tercantum, sehingga RPP ini dapat diterapkan langsung dalam kegiatan pembelajaran. Meskipun demikian ada beberapa aspek yang perlu diperhatikan agar dapat menghasilkan RPP yang lebih baik, yakni ketetapan penjabaran standar kompetensii, kompetensi dasar, kejelasan rumusan indikator, pengembangan indikator menjadi tujuan pembelajaran. Oleh karena itu, dilakukan revisi berdasarkan saran dari kedua validator. Saran-saran tersebut meliputi: (1) perangkat pembelajaran yang dikembangkan khususnya pada RPP harus jelas indikator pencapaian kompetensi dasar.(2) waktu sebaiknya dialokasikan sesuai dengan tahapann/fase-fase kegiatan guru dan peserta didik.

Secara umum nilai rata-rata total kevalidan rencana pelaksanaan pembelajaran yang diperoleh termasuk dalam kategori "Valid"
Pada lampiran D.6 menunukkan bahwa yang mencapai KKM sebanyak 21 siswa atau sebesar $87,5 \%$ sudah tercapai secara klasikal dengan KKM yang harus dicapai 75 .

sehingga di tinjau dari keseluruhan aspek, termasuk pelaksanaan pembelajaran dinyatakan memenuhi kriteria kevalidan, hasil akhir revisi perangkat tersebut merupakan perangkat daraf kedua yang dipakai pada uji coba perangkat.

2) Lembar Kerja Peserta Didik (LKPD)

Rata-rata penilaian terhadap LKPD dilihat dari aspek aktivitas, materi yang disajikan, bahasa dan waktu adalah kategori sangat Valid. Hal ini berartiLKPD yang disusun telah dikembangkan berdasarkan rasional teoritis yang kuat dan memiliki konsistensi internal yang kuat, yakni terjadi saling keterkaitan antar komponen dalam LKPD maupun Perangkat lain, sehingga LKPD ini dapat digunakan dalam kegiatan pembelajaran.

3) Tes hasil belajar

Rata-rata penilaian terhadap tes hasil belajar dilihat dari aspek materi soal, konstruksi, dan bahasa termasuk dalam kategori sangat valid, pesentage kesepahaman $100 \%$ atau 1,00. Secara umum semua penilaian validator terhadap perangkat pembelajaran yang dikembangkan memberikan kesimpulan yang sama yaitu perangkat pembelajaran ini baik dan dapat digunakan dengan sedikit revisi. Dalam melakukan revisi peneliti mengacu pada hasil diskusi dengan mengikuti saran-saran serta petunjuk validator.

Disamping perangkat tersebut diatas, instrument lainnya (lembar pengamatan aktivitas peserta didik, lembar pengelolaan pembelajaran, dan angket repon peserta didik) yang terkait dengan peneliti ini juga divalidasi. Hasil 
validasinya berada pada kategori sangat valid dan nilai reabilitas $(\mathrm{R}) \leq 0,75$ artinya berada pada kategori reliabel.

\section{b. Kepraktisan}

Secara umum, hasil penelitian ahli dan praktisi terhadap perangkat pembelajaran ekonomi berbasis literasi menyatakan bahwa perangkat layak digunakan dalam pembelajaran, sedangkan secara empirik, berdasarkan hasil pengamatan pada saat uji coba terhadap perangkat pembelajaran oleh dua observer menyatakan bahwa nilai keterlaksanaan perangkat sudah sesuai dengan harapan karena semua komponen-komponen yang menjadi penilaian daalam instrumen terlaksana seluruhnya. Begitu pun dengan respon guru terhadap pembelajaran berada pada kategori sangat positif. Hal ini berarti bahwa perangkat pembelajaran yang telah dikembangkan praktis dan dapat digunakan dalam pembelajaran ekonomi berbasis literasi.

Berdasarkan hasil penilaian pengamat, maka perangkat pembelajaran telah memenuhi kriteria kepraktisan.

\section{c. Keefektifan}

Dari hasil penelitian dikemukaka kriteria keefektifan pembelajaran yang meliputi:

1) Ketuntasan hasil belajar. Dari 27 peserta didik, umumnya peserta didik telah berada dalam kategori tuntas. Dengan demikian, menurut kriteria pada Bab III, penguasaan tes

Untuk mengkategorikan keefektifan suatu perangkat pembelajaran maka, 3 dari 4 indikator kriteria tersebut harus terpenuhi, tetapi indikator (1) harus terpenuhi. Dari keempat komponen di atas, pada saat uji coba keempat aspek berbasis literasi pada materi masalah ekonomi dan sistem ekonomi mememnuhi kriteria keefektifan.

\section{Respon peserta didik setelah mengikuti pembelajaran berbasis literasi informasi}

Respon peserta didik terhadap perangkat pembelajaran dibagi dalam dua aspek yaitu aspek

\section{SIMPULAN DAN SARAN}

\section{Simpulan}

Secara umum hasil pengembangan perangkat pembelajaran dalam penelitian ini valid, praktis, dan efektif. (a) Rencana Pelaksanaan Pembelajaran (RPP), Lembar Kerja Peserta Didik hasil belajar peserta didik sudah memenuhi standar ketuntasan klasikal. Pembelajaran ekonomi berbasis literasi dapat meningkatkan aktivitas dan hasik belajar peserta didik, dimana nilai rata-rata yang diperoleh peserta didik berada pada kategori tinggi.

2) Aktivitas peserta didik. Secara umum hasil analisis data aktivitas peserta didik menunjukkan bahwa aktivitas ke-1, ke-2 dan ke-3. Pada setiap pertemuan pertemuan yang diamati memiliki frekuensi dan persentase yang tinggi, ini berarti aktivitas peserta didik sesuai dengan yang diharapkan karena berada pada kategori sangat baik, karena persentase yang di dapatkan dari pertemuan ke tiga ratarata persentasenya mencapai $98 \%$. Penelitian ini dianggap berhasil karena aktivitas peserta didik berada dalam kategori sangat baik. Hal ini sejalan dengan hasil penelitian sebelumnya, dimana peneliti memuat indikator aktivitas peserta didik sesuai dengan tahapan literasi dan setiap pertemuan dinyatakan efektif karena aktifitas peserta didk berada kategori sangat baik.

3) Kemampuan guru mengelola pembelajaran. Hasil analisis data kemampuan guu mengelola pembelajaran berada dalam kategori "sangat baik".

4) Respon peserta didik. Dari keseluruhan aspek yang diamati rata-raa respon positif yang di berikan oleh peserta didik.

respon peserta didik terhadap perangkat pembelajaran dan proses pembelajaran, dan respon peserta didik terhadap LKPD. Tujuan utama analisis data respon peserta didik terhadap proses pembelajaran adalah untuk melihat bagaimana respon peserta didik terhadap pembelajaran berbasis literasi. Persentase ratarata respon peserta didik terhadap pembelajaran yang menggunakan perangkat pembelajaran berbasis literasi secara keseluruhan berada dalam kategori sangat baik atau sangat positif

(LKPD) dan Tes Hasil Belajar di kategorikan "Valid". Dan (b) rata-rata persentase respon peserta didik terhadap pembelajaran dengan menggunakan perangkat pembelajaran berbasis 
literasi secara keseluruhan berada pada kategori sangat baik atau sangat positif.

\section{Saran}

Berdasarkan hasil penelitian yang dilakukan, maka peneliti memberikan saran kepada pihak yang terkait bahwa perangkat pembelajaran yang dikembangkan dalam penelitian ini sudah memenuhi kriteria kualitas yang baik sehingga

\section{DAFTAR RUJUKAN}

Apriyani, Mega. (2010). Literacy Informasi Pemustaka : Studi Kasus Di Perpustakaan Umum Daerah Provinsi DKI Jakarta. Jakarta. Universitas Indonesia Fakultas Ilmu Pengetahuan Budaya.

Hasugian, J. 2008. Urgensi Literasi Informasi Dalam Kurikulum Berbasis Kompetensi Di Perguruan Tinggi. Pustaha : jurnal studi perpustakaan dan informasi, 4 (2) p. 34-44 (http://ced.perta.ac.id)

Mishra, R.N Ddan C.Mishra (2010). Relevance of information literacy in digital environment. Journal of emerging trends disarankan dapat diimplementasikan oleh guruguru dalam pembelajaran di kelas untuk materi masalah ekonomi dan sistem ekonomi.

Bagi peneliti yang berminat melakukan penelitian pengembangan perangkat agar mencermati segala kelemahan dan keterbatasan dalam penelitina ini, sehingga penelitian yang dilakukan dapat menghasilkan perangkat pembelajaran yang lebih valid, praktis, dan efektif.

$\begin{array}{lrr}\text { in computing } & \text { and } & \text { informating } \\ \text { science,1(1) } & \text { hal } & 48-54 \\ \text { (http://cisjournal.org) } & & \end{array}$

Mulyani Emi Tri. 2015. Model literasi informasi. UPT. Perpustakaan ISI Surakarta. (http://digilib.isi-iska.ac.id)

Trianto. 20013. Mendesain Model Pembelajaran Inovatif-Progresif. Surabaya: Kencana Prenada Media Group.

Trilling, Betnie and Fadel, Charles (2009). $21^{\text {st }}$ Century Skills; Learning For Life In Our Times, John Willey \& Sons, 978-0-4705536 